University of St. Thomas, Minnesota

UST Research Online

Operations and Supply Chain Management

Faculty Publications

Operations and Supply Chain Management

2012

\title{
Antecedents and Consequences of New Product Development Practices and Software Tools: An Exploratory Study
}

\author{
Gregory R. Heim \\ Texas A \& M University - College Station, gheim@mays.tamu.edu \\ Debasish N. Mallick \\ University of St. Thomas, Minnesota, dnmallick@stthomas.edu \\ Xiaosong (David) Peng \\ Texas A \& M University - College Station, peng@mays.tamu.edu
}

Follow this and additional works at: https://ir.stthomas.edu/ocbopmtpub

Part of the Business Administration, Management, and Operations Commons, Management Sciences and Quantitative Methods Commons, and the Operations and Supply Chain Management Commons

This Article is brought to you for free and open access by the Operations and Supply Chain Management at UST Research Online. It has been accepted for inclusion in Operations and Supply Chain Management Faculty Publications by an authorized administrator of UST Research Online. For more information, please contact asle4660@stthomas.edu. 


\title{
Antecedents and Consequences of New Product Development Practices and Software Tools: An Exploratory Study
}

\author{
Gregory R. Heim, Debasish N. Mallick, Member, IEEE, and Xiaosong (David) Peng
}

\begin{abstract}
Many development practices and software tools enable new product development (NPD), yet few empirical studies shed light on the project characteristics and project contexts driving their use. Using a cross-sectional sample of NPD projects, this study examines how project characteristics and availability of information technology (IT) infrastructure relate to the use of NPD practices and software tools. We also examine how the extent of their use is associated with NPD project performance. The results indicate that different project characteristics influence the use of NPD practices and software tools, with project complexity associated with software tool use, but project uncertainty associated with NPD practice use. Also, customer facing IT infrastructure is associated with the use of NPD practices, while manufacturing plant IT infrastructure is associated with the use of design/validation software tools. Moreover, use of NPD practices has a positive association with all project-level performance metrics examined in this study, and as a result, a greater impact on overall market success. In comparison, the performance impacts of software tools appear relatively limited, with only design/validation software tools exhibiting a strong positive association with product performance quality and a weak positive association with time-to-market and responsiveness. Communication/teamwork software tools exhibit no such impact.
\end{abstract}

Index Terms-Information processing theory, information technology (IT), new product development (NPD) performance, project management (PM), technology management.

\section{INTRODUCTION}

$\mathbf{M}$ ANY development practices, software tools, and other helpful aides enable new product development (NPD). These means for improving NPD outcomes include information organizing frameworks, design philosophies and rules of thumb, and software tools for performing detailed design tasks, communicating, collaborating, collecting information, and managing timelines and resources [1]. In the NPD literature, a distinction is often made between the software tools (tools for short) and NPD practices. Some representative software tools include computeraided design (CAD), computer-aided process planning (CAPP),

Manuscript received July 26, 2010; revised December 13, 2010, May 26, 2011, and August 23, 2011; accepted September 7, 2011. Date of publication November 23, 2011; date of current version July 13, 2012. Review of this manuscript was arranged by Department Editor Jeffrey K. Liker.

G. R. Heim and X. (David) Peng are with the Department of Information and Operations Management, Mays Business School, Texas A\&M University, College Station, TX 77843-4217 USA (e-mail: gheim@mays.tamu.edu).

D. N. Mallick is with the Department of Operations and Supply Chain Management, Opus College of Business, University of St. Thomas, Minneapolis, MN 55403 USA (e-mail: dnmallick@ stthomas.edu).

Digital Object Identifier 10.1109/TEM.2011.2172608 simulation modeling tools (SMTs), product data management (PDM) systems, project management (PM) software, e-mail, and groupware. Among the popular NPD practices (or techniques) are design for manufacturability (DFM), quality function deployment (QFD), and rapid prototyping (RPT) [2]-[10]. While proponents of certain NPD practices and software tools have written about their potential benefits, a deeper understanding of how NPD practices or software tools help manage NPD projects and ensure beneficial outcomes is essential for their effective use. However, little academic literature empirically examines these relationships [11], [12].

Prior studies have examined the impact of a single NPD practice or software tool [13], [14], the perceived support of the manager of information systems (MIS) department for the NPD team [12], [15], or the general level of information technology (IT) available to NPD teams [12], [16], [17]. Yet, to help project managers effectively deploy these practices and tools, researchers must focus on "careful consideration of their complex interplay with the product development context" [1, p. 8], i.e., the project characteristics and infrastructure around the project team. Moreover, focusing solely on a single software tool may lead to findings that inappropriately attribute the performance outcomes to a single tool rather than to pertinent project characteristics, infrastructure, or practices. To our knowledge, no study has examined both antecedents and consequences of the use of multiple practices and tools. This study addresses this literature gap through two research questions.

1) How do project characteristics and availability of IT infrastructure drive the use of NPD practices and software tools?

2) How does the use of NPD practices and software tools affect NPD performance?

We use data from a sample of NPD projects to explore the direct effect of three project characteristics (i.e., project scope, uncertainty, and complexity) and availability of three types of IT infrastructure (i.e., customer facing, manufacturing plant, and supplier facing) on the use of NPD practices (i.e., DFM, QFD, and RPT) and two types of software tools: design/validation tools (i.e., CAD, CAPP, SMT, and PDM) and communication/ teamwork tools (i.e., PM software, e-mail, and groupware). We also examine how the use of these NPD practices and software tools affects project-level performance and overall market success.

The results indicate that different project characteristics influence the use of NPD practices and software tools. Specifically, project complexity is associated with software tool use, whereas 
project uncertainty is associated with NPD practice use. Also, availability of specific types of IT infrastructure affects the use of NPD practices and software tools. Customer facing IT infrastructure is associated with the use of NPD practices, while manufacturing plant IT infrastructure is associated with the use of design/validation software tools. Moreover, use of NPD practices has a positive impact on all project-level performance metrics examined, and as a result, a greater impact on overall market success. In contrast, performance impacts of software tools are relatively limited (i.e., design/validation tools have a strong positive association with product performance quality and weak associations with time-to-market and responsiveness).

The study enriches the literature in several ways. First, the study provides empirical evidence of the influence of project characteristics and IT infrastructure on the use of NPD practices and software tools. Second, the study provides empirical evidence of the impact of NPD practices and software tools on various project-level performance variables. Finally, since these results were derived from data on actual use of practices and tools, they provide direct managerial insights on the benefits of IT infrastructure and on selection of NPD practices and software tools for achieving high product development performance and market success.

The paper is organized as follows. Section II reviews relevant literature and develops the theoretical model of this study as a set of testable hypotheses. Section III describes the data and the measures used in this study. Section IV presents the results. Section V discusses implications. Section VI summarizes contributions, limitations of this study, and directions for future research.

\section{THEORETICAL FOUNDATION AND HYPOTHESES DEVELOPMENT}

\section{A. Background}

Literature on NPD has experienced significant growth during the past 25 years. While a significant part of the literature focuses on issues related to the product development process and organization, only a handful of papers examine NPD practices and software tools and their effects on NPD performance. Even fewer papers examine effects of IT infrastructure on practice or tool use. The limited body of literature is mostly conceptual and anecdotal, with the little empirical evidence sometimes showing mixed results [11], [12], [18]-[20].

Several scholars recognize the rapid proliferation of software tools in NPD [1], [21]-[23]. Software tools can enhance the knowledge base available to an NPD team, automate tasks for idea generation and concept testing, and improve team coordination, communication, and cooperation [24]. These benefits may increase developer productivity, leading to cost and time reductions and higher product quality [18], [25]-[27].

Empirical evidence regarding the use of NPD software tools and its outcomes is scarce, and the limited findings are contradictory at times. A few case studies document successful use of software tools [28]-[31]. A survey of NPD projects found that high performing teams tend to use collaboration and communication software more than low performing teams [32]. Several studies report that software tools such as CAD/computer-aided engineering can improve the speed of product development [22], [33]. However, other research reports that NPD software tool use may not improve cost, speed-to-market, or flexibility [12], [34]. These contradictory findings led scholars to suggest that NPD software tool use may be contingent upon project environments [35], [36]. Thomke [37, p. 31] observes that "... the effectiveness of the same tool can be totally different depending on how the technology is deployed. It is the use of technology that determines whether value is created." Indeed, Bardhan et al. [16] report that alignment between software applications and project environment relates to speed, quality, and cost performance.

The aforementioned literature suggests our understanding of the effect of project characteristics and IT infrastructure on the use of NPD practices and tools remains incomplete. The extent to which practices and tools support NPD is potentially much broader than the scope addressed to date [1]. Thus, more research is needed on NPD practices and software tools [38].

\section{B. Research Framework and Variables}

We use organizational information processing theory (OIPT) as the foundation for our research hypotheses. OIPT has been used extensively in the NPD literature [2], [39]-[44]. According to OIPT, a match must exist between information processing needs and information processing capabilities in order to achieve the reasonable performance [45], [46]. We propose that the information processing needs of an NPD project are driven by project characteristics and infrastructure, and the use of the right NPD practices and software tools can provide needed information processing capabilities for the NPD project.

We present a high-level conceptual framework in Fig. 1. There are four proposed paths. First, NPD project characteristics are predicted to drive the use of NPD practices and software tools. Second, availability of IT infrastructure should stimulate and enable the use of NPD practices and software tools. Third, NPD practices and software tools are hypothesized to drive projectlevel performance outcomes. Fourth, these outcomes are expected to lead to overall market success. See Hypotheses 1-4 for details on specific hypothesized associations.

Before developing hypotheses, it is important to differentiate the two main constructs used in this study: NPD practices and software tools. Although many popular NPD practices initially were paper-based and did not require computers to make use of them, increasingly the practices are being implemented with IT-based platforms. Still, a conceptual distinction can be made between NPD practices and NPD software tools. NPD practices generally represent principles, frameworks, and methodologies for organizing and coordinating NPD activities. NPD software tools refer to software programs for automating NPD design tasks and facilitating information sharing and exchange. Prior studies explicitly model NPD practices and software tools as separate constructs [3], [5], [6]. Examining practices and software tools in parallel allows us to observe their individual performance impacts while controlling for the effect of each other. 


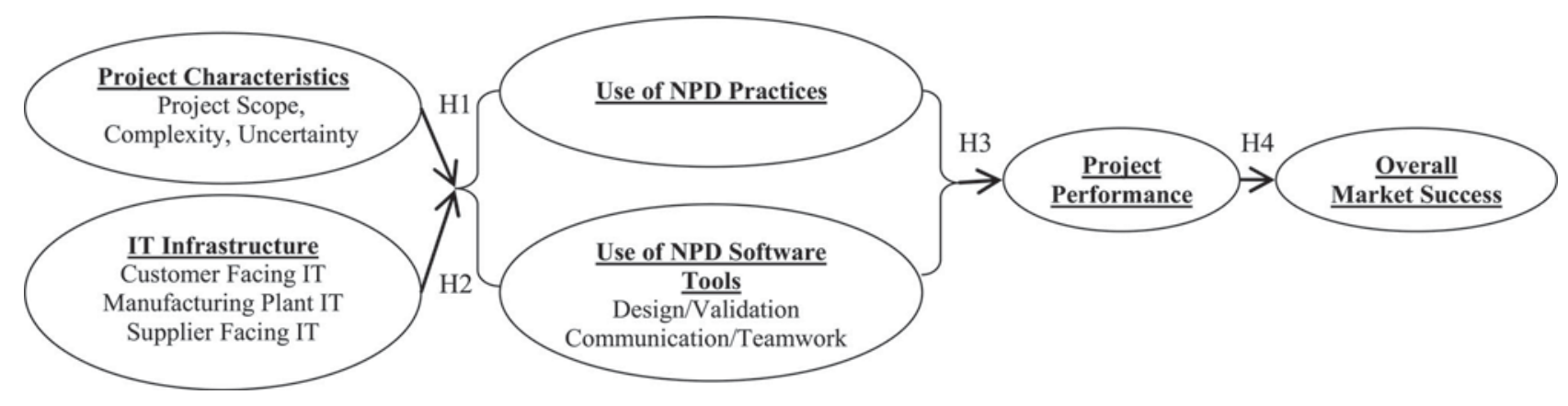

Fig. 1. Conceptual framework.

Next, we define the constructs and formally state their hypothesized associations.

1) NPD Practices: This study examines three NPD practices [2], [10]: DFM, QFD, and RPT. A significant contemporary trend in the management of NPD is "integrated product development" [8], which can be facilitated by NPD practices that enable overlapping NPD activities (e.g., partially or completely parallel execution). All three practices we examine are related to the integrated product development approach [8]. These practices enable NPD teams to structure customer demand information, transform that information into manufacturable product designs, and integrate and improve communication among customers, designers, marketing, and manufacturing operations [4], [47], [48]. DFM practices attempt to ensure that a product design can be manufactured within manufacturing plant constraints [33]. Design teams use DFM to simplify product designs, standardize parts and materials, mistake-proof design and assembly tasks, and design for easy assembly. $Q F D$ practices allow a project team to translate customer demands into engineering-oriented product design quality specifications [49]. QFD attempts to integrate the customer voice into the design process to achieve the customer's desired quality objectives. QFD often is associated with the house of quality (HOQ) [50] information organizing framework that captures customer quality dimensions and their importance, quality dimension interactions, interactions between company capabilities necessary to develop the product, and potential engineering challenges. $R P T$ focuses on quickly identifying customer needs and turning them into appropriate product features. RPT enables designers to quickly turn envisioned designs into product prototypes, get prototypes into customer hands for feedback, and incorporate the feedback into subsequent iterations [33], [51].

2) NPD Software Tools: NPD software tools are IT applications that team members use to accomplish development tasks. This study differentiates between use of NPD software tools and availability of broad IT infrastructure consisting of computer hardware, software applications, and telecommunication applications [52]. We propose that IT infrastructure can drive and facilitate the use of NPD practices and software tools by NPD teams. This point is discussed in detail later.

In a seminal paper, Huber [53] differentiates between decision aiding technologies and communication technologies. Decision aiding technologies enable individuals or organizations to store and access information, reconfigure existing information into new information and decision models, and support decision making related to problems at hand. Communication technologies enable individuals or organizations to communicate conveniently, cheaply, and rapidly, record communication content easily, and control communication participation effectively.

Few studies have examined NPD software tools. Accordingly, we are not aware of any typology of specific NPD software tools. However, the broad IT typology proposed by Huber [53] can serve as a conceptual foundation for grouping NPD software tools. We suggest that in NPD, decision aiding technologies include software tools such as CAD, CAPP, SMT, and PDM, while NPD communication technologies relate to software tools such as e-mail, groupware, and PM software. To develop a parsimonious research model, we identify them as: 1) design and validation tools; and 2) communication and teamwork tools, respectively. This view is consistent with prior study [11] that views product design tools (e.g., CAD) to be a separate category from tools for teamwork and PM. Huber's characterization of IT has been applied in prior related studies [54].

a) Design and validation tools: We examine four software tools for tasks involving product design, design validation, and process design [10]. $C A D$ systems allow designers to create and store a product design as a computer file. CAD software supports 2-D and 3-D design modeling, visualization, and simulation [81]. CAPP transforms engineering information from a CAD diagram into a computerized process plan for manufacturing the product. CAPP identifies processing steps to manufacture a product, while taking into account existing machine workload levels. SMTs allow product and process design teams to examine the interaction of design decisions before releasing products into manufacturing [26], [55]. Product simulations allow designers to examine geometric part interactions and material robustness. Process simulations examine manufacturing process efficiency for the new product. $P D M$ s enable group technology programs by managing data on discrete parts. Teams can search for data on existing parts already produced in-house or available from vendors.

b) Communication and teamwork tools: We examine two communication and teamwork tools for managing the NPD process [10], [11]. E-mail groupware provides team members with environments in which to brainstorm, share files, collaborate, and communicate [55]. These tools enable creation and storage of project vision and direction documents, management of project stages, and tracking of tasks. PM software facilitates 
basic management activities to control project schedules, timelines, resources, and tasks.

3) NPD Project Context: This section examines how important contextual factors (project characteristics and IT infrastructure), as suggested by the literature, drive the use of NPD practices and software tools.

a) Impact of project characteristics on NPD practices and tool use: The project characteristics investigated in this study include project scope, complexity, and uncertainty. Project scope represents the breadth of parts and components involved in the end product being designed [56]. Project complexity represents the extent to which a project may consist of a complex set of activities, participants, and departments. Project uncertainty occurs when projects involve breakthrough project designs, different characteristics from existing product lines, new markets, new product technologies, or new process technologies [7]. NPD teams must deal with information processing challenges resulting from the project characteristics and the available technologies that may be used for a project [57]. Differences in project characteristics represent differing project execution challenges, and with them, differing amounts and natures of information that an NPD team must process [42], [58]. Different project characteristics will create differentiated needs for NPD practices and software tools since a fit between each project characteristic and the required practices and tools must be achieved in order to execute project activities effectively.

The scope, complexity, and uncertainty of an NPD project create different information processing challenges as defined by the amount of information and the equivocality (ambiguity) of that information [59], [60]. We posit that project scope and complexity are more closely related with the amount of information to process, while project uncertainties are more closely related with the equivocality of information [61], [62]. In the former case, the main challenge for the NPD team is to develop the ability to process large amounts of structured information efficiently. In the latter case, due to the ambiguous information, the focus shifts to clarifying information ambiguity. Under this circumstance, it is important to clarify ambiguous information rather than simply obtain additional information. To process ambiguous information, project team members often have to discuss, debate, and negotiate intensively to reach consensus on project goals, schedules, and task execution. Thus, different information processing capabilities are required to meet the different information processing challenges created by the three project characteristics.

According to OIPT, structural mechanisms and information processing tools can be used to enhance an organization's information processing capability [45]. NPD practices and software tools are used by NPD teams to enhance the information processing capability required to meet the information processing challenges posed by project characteristics. However, the information processing capabilities they provide are quite different from each other since NPD practices are more effective for resolving ambiguity while software tools enable NPD teams to efficiently process large amounts of information. For instance, NPD teams can use CAD to create 3 -D visuals and blueprints quickly, display product specifications accurately, and quickly prepare large amounts of documentation for the production process. Software tools can also be used to manage the many interfaces between parts and modules. As the scope and complexity of a product increase, managing the vast amount of engineering design data can become a great challenge. Software tools can provide efficient information processing in such circumstances.

In contrast, when a great degree of uncertainty surrounds a project due to radically new product design, technology, and markets, an NPD team usually has no established procedures to follow. In this ambiguous circumstance, the NPD team needs to communicate face-to-face and jointly solve problems to a much greater extent. Using NPD practices can create an organizational infrastructure that facilitates regular design review meetings, brainstorming sessions, and formal or informal dialogues related to product development between different functions, and therefore, helps to clarify information ambiguity. When project uncertainties are high, it may be more important for NPD team members to communicate directly and jointly solve problems by following the integrated NPD practices than to rely on software tools for communication and collaboration. We summarize our arguments in the following hypotheses:

\footnotetext{
Hypothesis 1: Project managers will respond to project characteristics that require differing information needs through the use of NPD practices and software tools.
}

(H1A) Project scope will exhibit a positive association with design/validation tools and communication/teamwork tools.

(H1B) Project complexity will exhibit a positive association with design/validation tools and communication/teamwork tools.

(H1C) Project uncertainty will exhibit a positive association with NPD practices.

b) Impact of IT infrastructure on NPD practices and tool use: IT infrastructure can be defined as a shared computer and networking hardware and applications installed within a firm and used to run the firm's software applications [63]. At a business function level, end users often view shared business applications as IT infrastructure. To date, the impact of IT infrastructure on NPD activities has not been studied adequately [20], [64]. Prior empirical research finds IT infrastructure to be positively yet insignificantly associated with software tool use [12], [17]. These studies, however, capture IT infrastructure via a single, all-inclusive construct that aggregates all IT infrastructure. Prior literature suggests distinct contributions of three categories of IT infrastructure within manufacturer value nets [63]. Thus, following Weill et al. [63], we examine three general IT infrastructure classes: applications deployed to external customers (customer facing IT), toward suppliers (supplier facing IT), and internally focused infrastructure (manufacturing plant IT). We propose that available IT infrastructure should support, and thus, affect the use of NPD practices and software tools [12].

Customer facing IT infrastructure is oriented toward communicating and collaborating with customers. IT such as customer relationship management systems [16] and customer-oriented websites can enable customers to participate, collaborate on forecasting, and assist with configuring and ordering products [20]. However, customer facing IT can generate customer 
responses from multiple customer segments and channels. The diverse customer perspectives and expectations and the lack of a common language between customers and product designers commonly observed in NPD can lead to equivocal information about the exact product features and performance customers desire as well as the firm's ability to develop and make such products quickly and cost effectively [63]. Reducing this information equivocality requires the NPD team to frequently communicate, debate, and brainstorm internally and with relevant personnel outside the NPD team. As such, activities enabled by customer facing IT require NPD teams to follow the integrated product development approach more closely in order to reduce information ambiguity, thus enhancing the use of NPD practices. Doing so may require higher use of communication software tools to collect additional information from customers. However, as customers often do not directly perform detailed product design tasks, we do not expect an association between customer facing IT and design/validation tools.

Manufacturing plant IT infrastructure provides potentially beneficial additional capabilities for an NPD project team. Prior literature has found that manufacturing plant IT infrastructure such as enterprise information systems can enhance organizational capabilities and enable manufacturing processes [20]. A strong plant IT infrastructure also enables a wide range of NPD activities [65], [80]. With a broad array of plant IT infrastructure, users performing different strategic and operational activities (e.g., forecasting, capacity planning, procurement, and quality management) can use various aspects of plant IT infrastructure to generate a diverse set of information relevant to NPD. The high variety of information may create ambiguity among the NPD team about how to interpret the meaning of the relevant information. Since users inside a plant are commonly collocated, it is feasible and desirable for the NPD team to follow integrated NPD practices, organize cross-functional meetings, and communicate directly with relevant personnel to resolve information ambiguity. Thus, we propose that manufacturing plant IT infrastructure should drive greater use of NPD practices. Second, many manufacturing plant IT applications are built to enforce industry-wide software, data management (e.g., CAD files), and communication standards [63]. These standards help to enable streamlined information throughput. As such, manufacturing IT infrastructure can interface plant applications directly to NPD teams' software tools, and facilitate quick and easy team sharing of large amounts of project-related information [12]. Thus, plant IT infrastructure should exhibit a positive relationship with the use of design/validation tools and communication/teamwork tools.

Supplier facing IT infrastructure such as EDI and product data management systems can make it easier for NPD teams to share product design documents with design firms and vendors, support collaborative design activities, and facilitate procurement of parts [20]. IT architecture and standards simplify the process of linking to and transacting with suppliers [63]. From an OIPT perspective, communication at a distance with many potential suppliers may generate ambiguous information about component specifications and supplier bid offers. Supplier facing IT infrastructure may necessitate a process for reducing bid information disparities and resolving ambiguous information through communication and collaboration enabled by NPD practices [63]. Supplier facing IT transactions may necessitate follow-up e-mail communication to remediate ambiguity. Thus, we expect supplier facing IT should positively affect the use of NPD practices and communication/teamwork tools. Since many suppliers facing IT applications focus on transmitting supplier bid and order data that need not comply with design software standards, we do not expect supplier facing IT to drive higher use of design/validation tools.

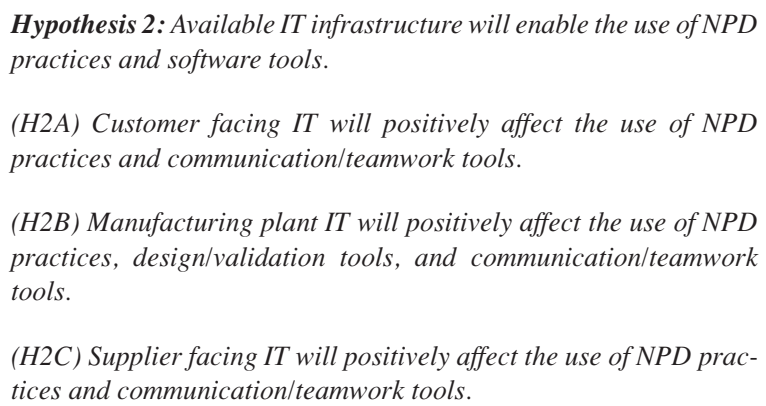

Hypothesis 2: Available IT infrastructure will enable the use of NPD practices and software tools.

(H2A) Customer facing IT will positively affect the use of NPD practices and communication/teamwork tools.

(H2B) Manufacturing plant IT will positively affect the use of NPD practices, design/validation tools, and communication/teamwork tools.

(H2C) Supplier facing IT will positively affect the use of NPD practices and communication/teamwork tools.

4) NPD Practices, Software Tool Use, and Performance: NPD teams must attempt to achieve many performance outcomes simultaneously [11]. In this study, we focus on five project-level performance measures: time-to-market, product performance quality, product conformance quality, responsiveness, and cost control. We also focus on overall market success. These performance measures are used widely in the NPD literature, (e.g., [12], [14], [36], [66], [67]).

NPD practices and software tools can provide improved information processing capability for an NPD team, and therefore, according to OIPT, use of NPD practices and tools in response to the NPD team's information processing needs should lead to improved project performance. Improved project performance should, in turn, lead to overall market success [68]-[70]. First, we explain why the use of NPD practices such as DFM, QFD, and RPT should be positively associated with project outcomes. Literature suggests that NPD practices oriented toward integrated product development can help teams improve the communication with customers, enhance necessary product features, and eliminate unnecessary features, and in doing so, avoid unnecessary costs and speed up time-to-market [47]. This is because extensive use of NPD practices for organizing design information should improve the gathering of customer data on customer needs, facilitate cross-functional communication and coordination among project team members, and enhance the project team's information processing capability.

NPD practices facilitate early release of preliminary information to the downstream stakeholders and provide improved visibility into change management processes so that the NPD team can better coordinate future design iterations and avoid frequent design adjustments [71]. By mitigating frequent downstream design changes, product quality should improve [14]. The coordination and information sharing enabled by NPD practices help the NPD team to find and resolve problems or disagreements early in the design process. Early problem solving can reduce costly changes late in the process, which would consume 
significant time and resources. Thus, NPD practices should improve time-to-market and cost control.

With respect to the NPD practices examined in our study, DFM and QFD can help translate customer desires into structured, actionable engineering information. Such information organizing capabilities will help improve outcomes for product quality and responsiveness to customer special requests. Swink [47] finds that DFM and QFD help accelerate projects, improving time-to-market. RPT can help the NPD team to quickly and iteratively determine the best features for a product, and therefore, enhance the performance quality. Iterative prototyping practices, in close contact with customers, should condense the project, leading to cost and time savings. Thus, RPT should improve product quality, cost, and time-to-market advantages.

Literature also suggests that software tools should be positively associated with project performance [17], [72]. However, we propose that the two types of software tools considered in this study will improve the project performance in different ways. Design and validation tools such as CAD, CAPP, SMT, and PDM are software tools developed specifically for improving the efficiency and effectiveness of specific design activities such as creating quality attributes of the product to meet product design specifications. Thus, we expect that the use of these software tools should be positively associated with the quality and cost of the product design as well as speed of development processes. For example, CAD and PDM are used to facilitate part management and reuse. For parts already produced within a firm, part engineering diagrams may be archived within the parts database, allowing project teams to reuse and modify existing $\mathrm{CAD}$ files for those parts. Thus, we expect that such tools will support lower development costs. The digital designs can be simulated to test physical properties and improve the conformance quality. The designs can be ensured to be feasible to manufacture using CAPP. Using such software tools may shorten the time to respond to customer demands for customized products, yet at the same time keep the product cost reasonable [1], [73]. Thus, we expect that design and validation tools will improve the product quality and responsiveness to customer requests.

Communication and teamwork software today play major roles in PM [14], [31]. Communication/teamwork tools such as e-mail/groupware and PM tools are intended for more generic activities such as communication, coordination, and resource allocation rather than specific design tasks. Hence, we expect such tools primarily to affect the project-level performance measures related to schedule and budget [67], but not to substantially affect quality or responsiveness. Such tools focus on enhancing NPD project decisions, facilitating the PM process, managing project workflows, and coordinating team member communications [11], [74], [75]. E-mail groupware is used as electronic communication channels among NPD team members and stakeholders. E-mail groupware can transform the way documents are shared to facilitate effective team collaboration [28]. Extensive use of e-mail and teamwork tools should speed up communication between customers, marketing, product designers, and parts suppliers. PM tools should help managers keep projects under budget. NPD teams use PM software to coordinate and schedule tasks and manage project resources. Sophisticated PM software has real-time workflow management capabilities to help coordinate NPD team member activities [1]. Using communication and PM software should directly affect project timelines [47]. Thus, we expect that use of communication and teamwork tools should reduce design cycle times and enhance project cost control.

\begin{abstract}
Hypothesis 3: NPD project performance will be affected by the use of NPD practices and software tools as follows:

(H3A) NPD practices will be positively associated with time-tomarket, product performance quality, conformance quality, responsiveness, and cost control.

(H3B) Design/validation tools will be positively associated with time-to-market, product performance quality, conformance quality, responsiveness, and cost control.

(H3C) Communication/teamwork tools will be positively associated with time-to-market and cost control.
\end{abstract}

Project-level NPD performance outcomes should positively affect product market outcome [76]. Time-to-market can affect product market success because there may be a limited window of opportunity for new products to realize optimal financial performance. Losing first-mover advantage often means substantially lower profitability. The ability to respond quickly to changes in the market and customer tastes and to introduce new products targeting these changes can potentially create considerable market success. Prior studies suggest that the superiority of a product's perceived quality is directly related to the product's market success, because high product quality suggests that the product created is close to the product desired by the marketplace [47]. Better product quality is often correlated with a better ability to meet customer needs [76]. Low product unit price should also positively affect the product's market success since lower cost means more value to customers, assuming that product quality is not compromised. Ability to control product development costs and unit manufacturing costs allows firms to price the product more aggressively, and therefore, gain market share. Thus, we propose:

Hypothesis 4: Time-to-market, product performance quality, product conformance quality, responsiveness, and cost control will positively affect overall market success.

\section{DATA AND METhODOlOGY}

\section{A. Data}

We use primary data collected specifically for this study as part of a larger study on manufacturing industries. The survey was administered as part of the fourth round of a global study on high-performance manufacturing (HPM) in 2006. HPM is a study on global manufacturing, for which a multiuniversity team of researchers gathered cross-sectional data on strategy, practices, and performance from an international study sample of manufacturing plants across three industries and nine countries. See Schroeder and Flynn [77] for more information. The overall data set includes 266 plants, from which data were collected using mailed surveys. Depending upon the content of 
TABLE I

VARIABLE DEFINITIONS AND SURVEY RESPONDENTS

\begin{tabular}{|c|c|c|}
\hline Variables & Respondent & Description \\
\hline \multicolumn{3}{|c|}{ Project Characteristics (See Appendix Table A1) } \\
\hline Project Scope & PD & $\begin{array}{l}\text { Product is a part/component (smallest scope }=1) \text {, module }(=2) \text {, assembly }(=3) \text {, system of components (largest scope }= \\
\text { 4). (4-point index) }\end{array}$ \\
\hline Project Complexity & PD & Project involved many tasks, departments. (Likert 7-point scale) \\
\hline Project Uncertainty & PD & $\begin{array}{l}\text { Project involved breakthrough design, new product, new product markets, new product technology, new process } \\
\text { technology. (3-point index) }\end{array}$ \\
\hline \multicolumn{3}{|l|}{ IT Infrastructure (See Appendix Table A2) } \\
\hline Customer Facing IT & MIS & Marketing, product configuration, ordering, and sales activities (7) supported via the Internet. \\
\hline Manufacturing Plant IT & MIS & Application areas (31) supported by software at the plant. \\
\hline Supplier Facing IT & MIS & Purchasing and supply chain management activities (8) supported via the Internet. \\
\hline \multicolumn{3}{|l|}{ NPD Practices and tools } \\
\hline \multirow[t]{2}{*}{ NPD practices (a) } & PD & $\begin{array}{l}\text { Please indicate the extent to which the following tools for product development were used in this project: Extensive (= } \\
\text { 7)/Very High/Somewhat High/Moderate/Somewhat Low/Very Low/Not At All (=1) (7-point items) }\end{array}$ \\
\hline & & $\begin{array}{l}\text { Design for Manufacturability (DFM), } \\
\text { Quality Function Deployment/House of Quality (QFD/HOQ) } \\
\text { Rapid Prototyping (RPT) }\end{array}$ \\
\hline \multirow{2}{*}{$\begin{array}{l}\text { NPD software tools (b) } \\
\qquad \text { Design/Validation Tools }\end{array}$} & PD & $\begin{array}{l}\text { Please indicate the extent to which the following tools for product development were used in this project: Extensive (= } \\
\text { 7)/Very High/Somewhat High/Moderate/Somewhat Low/Very Low/Not At All (=1) (7-point items) }\end{array}$ \\
\hline & & $\begin{array}{l}\text { Computer Aided Design (CAD) } \\
\text { Computer Aided Process Planning (CAPP) } \\
\text { Simulation modeling (SMT) } \\
\text { Shared parts databases (PDM) }\end{array}$ \\
\hline Communication/Teamwork Tools & & $\begin{array}{l}\text { E-mail, groupware } \\
\text { Project management software }\end{array}$ \\
\hline \multicolumn{3}{|l|}{ NPD performance (6) (See Appendix Table A1) } \\
\hline $\begin{array}{l}\text { Overall Market Success } \\
\text { Time to Market } \\
\text { Product Performance Quality } \\
\text { Product Conformance Quality } \\
\text { Responsiveness } \\
\text { Cost Control }\end{array}$ & PD & $\begin{array}{l}\text { Please rate the success of this product development project, relative to its goals: Significantly Better/Better/Somewhat } \\
\text { Better/About The Same/Somewhat Worse/Worse/Significantly Worse (7-point items) }\end{array}$ \\
\hline \multicolumn{3}{|l|}{ Control Variables (See Appendix Table A1) } \\
\hline Electronic & & Indicator variable; relative to Transportation \\
\hline Machinery & & Indicator variable; relative to Transportation \\
\hline Asian Plant & & Indicator variable; relative to European Plant \\
\hline USA Plant & & Indicator variable; relative to European Plant \\
\hline
\end{tabular}

each questionnaire item, one or multiple key informants were used to obtain data, with the survey respondents spanning from shop floor operators through top management. The breadth of variables collected makes the data set quite useful for examining the role of NPD practices and software tools in NPD.

\section{B. Measures}

1) Measurement Items: The unit of analysis for our study is an NPD project in which an employee at the manufacturing plant had participated. Table I presents variable and respondent information for the variables used. In addition to the main variables discussed in Section II, we included control variables for industry factors and nation/regional factors that potentially affect new product design success. Measurement items are presented in Tables A1 and A2 of the Appendix.

2) Validation of Measurement Items: Since the practice, tool, and project performance data were self-reported by a single member of the NPD team, we ruled out significant common method bias (CMB) by employing Harman's one-factor test [78], [79], commonly used in related research [12], [14], [16]. To perform Harman's test, all of the performance measures and project characteristic measures were entered into a single exploratory factor analysis to determine whether a single factor would account for the majority of covariance in the measures. No single dominant factor emerged. Instead, we observed multiple factors, with performance and project characteristics loading on different factors. This finding suggests that $\mathrm{CMB}$ is not evident in our data [78].

Confirmatory factor analyses were used to establish convergent validity and discriminant validity of the items. Convergent validity was estimated through confirmatory factor analysis (CFA) using maximum likelihood estimation in SPSS AMOS. The CFA model for the NPD performance variables indicated that each item loaded significantly $(p<0.001)$ on its corresponding latent construct. The performance variables have an acceptable data-to-model fit, as demonstrated by various fit indices $\left(\chi^{2}=126.784, d f=67, \chi^{2} / d f=1.892\right.$, normed fit index $(\mathrm{NFI})=0.904$, non-NFI $(\mathrm{NNFI})=0.923$, comparative fit index $(\mathrm{CFI})=0.951$, and root-mean-squared error of approximation $($ RMSEA $)=0.058)$. The project characteristic scales were included in a second CFA, with results indicating a good data-tomodel fit $\left(\chi^{2}=100.608, d f=71, \chi^{2} / d f=1.417, \mathrm{NFI}=0.883\right.$, $\mathrm{NNFI}=0.942, \mathrm{CFI}=0.961$, and RMSEA $=0.040$ ).

Discriminant validity was examined via pairwise chi-square difference tests between constrained correlation (to 1) and unconstrained models. The unconstrained models exhibited chisquare $(d f=1)$ statistics significantly different $(p<0.005)$ from the constrained models, providing evidence supporting discriminant validity. We also computed composite reliability for each scale. Most of the scales have composite reliability above 0.70 , with only a few variables slightly below, indicating satisfactory scale reliability [80]. After performing these tests, each variable was constructed by taking the simple arithmetic 
TABLE II

Summary STATISTICS AND CORRELATIONS FOR ANTECEDENT AND CONSEQUENCE VARIABLES

\begin{tabular}{|c|c|c|c|c|c|c|c|c|c|c|c|c|c|c|c|}
\hline & $\alpha$ & $\beta$ & $\gamma$ & 8 & $\varepsilon$ & 5 & A & B & C & $\mathrm{X} 1$ & $\mathrm{X} 2$ & $\mathrm{X} 3$ & IT1 & IT2 & IT3 \\
\hline$\alpha$. Overall Market Success & 1.000 & & & & & & & & & & & & & & \\
\hline$\beta$. Time to Market & $0.490^{t}$ & 1.000 & & & & & & & & & & & & & \\
\hline . Product Performance Quality & $0.407^{t}$ & $0.257^{\dagger}$ & 1.000 & & & & & & & & & & & & \\
\hline 8. Product Conformance Quality & $0.264^{T}$ & $0.277^{7}$ & $0.587^{?}$ & 1.000 & & & & & & & & & & & \\
\hline ह. Responsiveness & $0.327^{l}$ & $0.291^{1}$ & $0.476^{?}$ & $0.441^{?}$ & 1.000 & & & & & & & & & & \\
\hline C. Cost Control & $0.328^{2}$ & $0.254^{\dagger}$ & $0.212^{\dagger}$ & 0.144 & 0.161 & 1.000 & & & & & & & & & \\
\hline A. NPD Practices & $0.325^{!}$ & $0.321^{\frac{1}{2}}$ & $0.156^{*}$ & $0.137^{*}$ & $0.272^{t}$ & $0.241^{t}$ & 1.000 & & & & & & & & \\
\hline B. Design/Validation Tools & $0.196^{\dagger}$ & $0.231^{2}$ & $0.177^{*}$ & 0.036 & $0.179^{*}$ & $0.161^{*}$ & $0.297^{5}$ & 1.000 & & & & & & & \\
\hline C. Communication/Teamwork Tools & $0.233^{t}$ & $0.217^{\frac{4}{4}}$ & $0.188^{\dagger}$ & 0.070 & $0.205^{\dagger}$ & $0.198^{\dagger}$ & $0.370^{\ddagger}$ & $0.506^{2}$ & 1.000 & & & & & & \\
\hline XI. Project Scope & 0.000 & 0.064 & $0.250^{2}$ & $0.163^{*}$ & $0.172^{*}$ & 0.063 & 0.115 & $0.203^{*}$ & 0.087 & 1.000 & & & & & \\
\hline X2, Project Complexity & $0.165^{*}$ & 0.109 & $0.256^{1}$ & 0.046 & 0.098 & 0.026 & $0.188^{+}$ & $0.336^{+}$ & $0.335^{5}$ & $0.165^{*}$ & 1.000 & & & & \\
\hline X3. Project Uncertainty & 0.077 & 0.051 & 0.124 & 0.047 & 0.033 & 0.040 & $0.177^{\circ}$ & $0.199^{+}$ & $0.201^{*}$ & $0.148^{*}$ & 0.319 & 1.000 & & & \\
\hline ITI. Customer Facing IT & 0.117 & 0.102 & $0.228^{\dagger}$ & $0.153^{*}$ & $0.193^{\dagger}$ & 0.079 & 0.104 & -0.026 & -0.004 & 0.069 & 0.024 & $-0.261^{F}$ & 1.000 & & \\
\hline IT2. Manufacturing Plant IT & -0.028 & -0.012 & $0.159^{*}$ & -0.020 & 0.134 & -0.018 & -0.061 & $0.169^{*}$ & 0.095 & 0.102 & $0.161^{*}$ & 0.042 & 0.109 & 1.000 & \\
\hline IT3. Supplier Facing IT & 0.083 & 0.055 & 0.066 & -0.035 & 0.043 & 0.019 & 0.028 & -0.004 & -0.015 & 0.085 & 0.123 & -0.103 & $0.439^{t}$ & 0.070 & 1.000 \\
\hline Mean & 4.831 & 4.351 & 5.115 & 4.930 & 5.020 & 4.274 & 3.920 & 4.516 & 4.291 & 2.712 & 5.442 & 1.508 & 2.358 & 14.620 & 2.854 \\
\hline Standard Deviation & 1.060 & 1.474 & 0.864 & 0.887 & 1.066 & 1.107 & 1.235 & 1.160 & 1.581 & 1.153 & 0.914 & 0.440 & 1.647 & 7.055 & 1.874 \\
\hline
\end{tabular}

${ }^{*} p<0.05,{ }^{4} p<0.01,{ }^{p} p<0.001$.

average of the included items. This practice is consistent with the approach found in several prior works employing regression analysis [12], [14]. Table II provides variable summary statistics and a correlation matrix.

\section{Empirical Analysis}

We examined the research hypotheses through simultaneous estimation of a recursive system of linear equations. The following model was estimated:

Antecedents of practice and tool use:

1) $Y_{\mathrm{DP}}=\chi_{0}+\chi_{1} X_{\mathrm{PU}}+\chi_{2} \mathrm{IT}_{C}+\chi_{3} \mathrm{IT}_{M}+\chi_{4} \mathrm{IT}_{S}+B Z_{\mathrm{DP}}$ $+\varepsilon_{\mathrm{OP}}$

2) $Y_{\mathrm{DT}}=\psi_{0}+\psi_{1} X_{\mathrm{PS}}+\psi_{2} X_{\mathrm{PC}}+\psi_{3} \mathrm{IT}_{M}+B Z_{\mathrm{DT}}+$ $\varepsilon_{\mathrm{DT}}$

3) $Y_{\mathrm{CT}}=\omega_{0}+\omega_{1} X_{\mathrm{PS}}+\omega_{2} X_{\mathrm{PC}}+\omega_{3} \mathrm{IT}_{C}+\omega_{4} \mathrm{IT}_{M}+$ $\omega_{5} \mathrm{IT}_{S}+B Z_{\mathrm{CT}}+\varepsilon_{\mathrm{CT}}$

Consequences of practice and tool use:

4) $Y_{\mathrm{TTM}}=\beta_{0}+\beta_{1} Y_{\mathrm{DP}}+\beta_{2} Y_{\mathrm{DT}}+\beta_{3} Y_{\mathrm{CT}}+B Z_{\mathrm{TTM}}+$ $\varepsilon_{\mathrm{TTM}}$

5) $Y_{\mathrm{PPQ}}=\gamma_{0}+\gamma_{1} Y_{\mathrm{DP}}+\gamma_{2} Y_{\mathrm{DT}}+B Z_{\mathrm{PPQ}}+\varepsilon_{\mathrm{PPQ}}$;

6) $Y_{\mathrm{PCQ}}=\delta_{0}+\delta_{1} Y_{\mathrm{DP}}+\delta_{2} Y_{\mathrm{DT}}+B Z_{\mathrm{PCQ}}+\varepsilon_{\mathrm{PCQ}}$;

7) $Y_{\mathrm{RES}}=\zeta_{0}+\zeta_{1} Y_{\mathrm{DP}}+\zeta_{2} Y_{\mathrm{DT}}+B Z_{\mathrm{RES}}+\varepsilon_{\mathrm{RES}}$;

8) $Y_{\mathrm{COC}}=\eta_{0}+\eta_{1} Y_{\mathrm{DP}}+\eta_{2} Y_{\mathrm{DT}}+\eta_{3} Y_{\mathrm{CT}}+B Z_{\mathrm{COC}}+$ $\varepsilon_{\mathrm{COC}}$.

Overall market success:

9) $Y_{\mathrm{OMS}}=\alpha_{0}+\alpha_{1} Y_{\mathrm{TTM}}+\alpha_{2} Y_{\mathrm{PPQ}}+\alpha_{3} Y_{\mathrm{PCQ}}+\alpha_{4} Y_{\mathrm{RES}}$ $+\alpha_{5} Y_{\mathrm{COC}}+\varepsilon_{\mathrm{OMS}}$

where error terms $(\varepsilon s)$ are assumed to be normally distributed with mean 0 and variance $\sigma_{i}^{2}$ unique to equation $i$. Since the project performance outcomes and use of practices and tools arise from related processes, the error terms from each equation are likely to be correlated; thus, we assume that the error terms will have nonzero covariance $\sigma_{i j}$ between equations $i$ and $j$.

Equations in steps 1)-3) examine antecedents of the extent of use of each NPD practice or tool group using the variables: $Y_{\mathrm{DP}}$ $=$ average $(\mathrm{DFM}, \mathrm{QFD}, \mathrm{RPT}), Y_{\mathrm{DT}}=\operatorname{average}(\mathrm{CAD}, \mathrm{CAPP}$, SMT, PDM), and $Y_{\mathrm{CT}}=$ average(e-mail/groupware, PM software). $X_{\mathrm{PS}}$ is the project scope and $X_{\mathrm{PC}}$ is the project complexity, while $X_{\mathrm{PU}}$ is the project uncertainty. $\mathrm{IT}_{C}$ is the customer facing IT and $\mathrm{IT}_{S}$ is the supplier facing IT, while $\mathrm{IT}_{M}$ is the manufacturing plant IT. In steps 1)-8), the $B Z$ term represents an equation-specific set of parameters $(B)$ for a set of industry and geographic control variables $(Z)$ (e.g., electronics industry, machinery industry, Asian plant, and U.S. plant).

Equations in steps 4)-8) estimate the impact of NPD practices, software tools, and controls on NPD project performance, using: $Y_{\mathrm{TTM}}=$ time-to-market, $Y_{\mathrm{PPQ}}=$ product performance quality, $Y_{\mathrm{PCQ}}=$ product conformance quality, $Y_{\mathrm{RES}}=$ responsiveness, and $Y_{\mathrm{COC}}=$ cost control. Equation in step 9) estimates how NPD project performance relates to overall market success $\left(Y_{\mathrm{OMS}}\right)$.

We analyzed the equations using seemingly unrelated regression (SUR) [81], [82] that related studies use [14]. SUR is appropriate for this set of equations since each outcome is hypothesized to be caused by related sets of causal drivers and similar processes, potentially leading to correlated residuals between the equations. Breusch-Pagan tests were rejected ( $p<$ 0.001 ) within each subset of antecedent and consequence equations, indicating that SUR is appropriate. In recursive equations, ordinary least squares regression will provide consistent, but not efficient, estimates. SUR leads to potentially more efficient estimates. The equations were estimated using the Stata reg3 procedure [83] that uses listwise deletion on missing observations.

Before estimating the final regression model, we examined diagnostics to rule out data condition issues and potential violations of regression assumptions. We examined variance inflation factor (VIF) statistics and condition numbers for the right-handside exogenous variable subsets for each equation. Each statistic is an indicator of potential multicollinearity. We observed no worrisome VIF statistics (all were less than 1.4) or condition numbers (all were far below the recommended threshold of 30). To rule out heteroskedastic errors, we performed Levéne-style statistical tests for heteroskedasticity of residuals due to sampling design (i.e., by industry and country) for the models, again observing no problematic statistics.

\section{RESULTS}

Table III presents SUR estimates for the antecedents of practice and tool use (columns 1-3), the consequences of their use upon project-level performance (columns $4-8$ ), and the 
TABLE III

SUR OF EXTENT OF USE OF NPD PRACTICES AND TOOLS AND NPD PERFoRMANCE

\begin{tabular}{|c|c|c|c|c|c|c|c|c|c|}
\hline & \multicolumn{3}{|c|}{ Antecedents of NPD Practices \& Tools } & \multicolumn{6}{|c|}{ Consequences of NPD Practices and Tools } \\
\hline & 1 & 2 & 3 & 4 & 5 & 6 & 7 & 8 & 9 \\
\hline & $\begin{array}{c}\text { NPD } \\
\text { Practices }\end{array}$ & $\begin{array}{l}\text { Design/ } \\
\text { Validation } \\
\text { Tools }\end{array}$ & $\begin{array}{c}\text { Commun./ } \\
\text { Teamwork } \\
\text { Tools }\end{array}$ & $\begin{array}{c}\text { Time } \\
\text { To } \\
\text { Market }\end{array}$ & $\begin{array}{c}\text { Product } \\
\text { Performance } \\
\text { Quality }\end{array}$ & $\begin{array}{c}\text { Product } \\
\text { Conformance } \\
\text { Quality }\end{array}$ & Responsiveness & Cost Control & $\begin{array}{l}\text { Overall } \\
\text { Market } \\
\text { Success }\end{array}$ \\
\hline Constant & $\begin{array}{c}-0.984 \\
(0.027)^{*}\end{array}$ & $\begin{array}{c}-2.254 \\
(0.000)^{* * * *}\end{array}$ & $\begin{array}{c}-1.851 \\
(0.004)^{*}\end{array}$ & $\begin{array}{c}4.300 \\
(0.000)^{* * * *}\end{array}$ & $\begin{array}{c}4.961 \\
(0.000)^{* * * *}\end{array}$ & $\begin{array}{c}4.876 \\
(0.000)^{* * * *}\end{array}$ & $\begin{array}{c}5.142 \\
(0.000)^{* * *}\end{array}$ & $\begin{array}{c}4.011 \\
(0.000)^{* * *}\end{array}$ & $\begin{array}{c}1.173 \\
(0.020)^{*}\end{array}$ \\
\hline Time To Market & $\cdots$ & - & - & $\cdots$ & - & $\ldots$ & - & $-\cdots$ & $\begin{array}{c}0.240 \\
(0.000)^{* * * *}\end{array}$ \\
\hline Performance Quality & $\cdots$ & $\cdots$ & $\cdots$ & $\cdots$ & $\cdots$ & $\cdots$ & $\cdots$ & $\cdots$ & $\begin{array}{c}0.237 \\
(0.032)^{*}\end{array}$ \\
\hline Conformance Quality & $\cdots$ & $\cdots$ & $\cdots$ & $\cdots$ & - & $\cdots$ & $\cdots$ & $\cdots$ & $\begin{array}{l}-0.058 \\
(0.584)\end{array}$ \\
\hline Responsiveness & $\cdots$ & $\cdots$ & - & $\cdots$ & - & $\cdots$ & $\cdots$ & $\cdots$ & $\begin{array}{c}0.163 \\
(0.057) \dagger\end{array}$ \\
\hline Cost Control & $\cdots$ & $\cdots$ & $\cdots$ & $\cdots$ & - & $\cdots$ & +- & $\cdots$ & $\begin{array}{c}0.200 \\
(0.003)^{* * *}\end{array}$ \\
\hline NPD Practices & $\cdots$ & $\cdots$ & $\cdots$ & $\begin{array}{c}0.316 \\
(0.004)^{* *}\end{array}$ & $\begin{array}{c}0.198 \\
(0.002)^{* * *}\end{array}$ & $\begin{array}{c}0.180 \\
(0.009)^{* *}\end{array}$ & $\begin{array}{c}0.262 \\
(0.001)^{* * * *}\end{array}$ & $\begin{array}{c}0.297 \\
(0.001)^{* * *}\end{array}$ & - \\
\hline $\begin{array}{l}\text { Design/Validation } \\
\text { Software Tools }\end{array}$ & $\cdots$ & $\cdots$ & $\ldots$ & $\begin{array}{c}0.245 \\
(0.052) \dagger\end{array}$ & $\begin{array}{c}0.277 \\
(0.000)^{* * *}\end{array}$ & $\begin{array}{c}0.110 \\
(0.131)\end{array}$ & $\begin{array}{c}0.153 \\
(0.070) \dagger\end{array}$ & $\begin{array}{l}-0.084 \\
(0.411)\end{array}$ & - \\
\hline $\begin{array}{l}\text { Commun./ Teamwork } \\
\text { Software Tools }\end{array}$ & $\cdots$ & - & $\cdots$ & $\begin{array}{c}0.111 \\
(0.196)\end{array}$ & - & - & $\cdots$ & $\begin{array}{c}0.056 \\
(0.447)\end{array}$ & - \\
\hline Project Scope & $\cdots$ & $\begin{array}{c}0.100 \\
(0.132)\end{array}$ & $\begin{array}{c}0.042 \\
(0.658)\end{array}$ & $\ldots$ & $\cdots$ & $\cdots$ & -- & -- & -- \\
\hline Project Complexity & $\cdots$ & $\begin{array}{c}0.346 \\
(0.000)^{* * *}\end{array}$ & $\begin{array}{c}0.432 \\
(0.000)^{* * *}\end{array}$ & $\cdots$ & - & $\cdots$ & $\cdots$ & -- & $\cdots$ \\
\hline Project Uncertainty & $\begin{array}{c}0.566 \\
(0.004)^{* *}\end{array}$ & - & - & $\cdots$ & - & $\cdots$ & - & $\cdots$ & $\cdots$ \\
\hline Customer Facing IT & $\begin{array}{c}0.188 \\
(0.001)^{* * *}\end{array}$ & $\cdots$ & $\begin{array}{c}0.034 \\
(0.594)\end{array}$ & $\cdots$ & $\cdots$ & $\cdots$ & $\cdots$ & $\cdots$ & $\cdots$ \\
\hline $\begin{array}{l}\text { Manufacturing Plant } \\
\text { IT }\end{array}$ & $\begin{array}{l}-0.006 \\
(0.639)\end{array}$ & $\begin{array}{c}0.027 \\
(0.013)^{*}\end{array}$ & $\begin{array}{c}0.020 \\
(0.184)\end{array}$ & $\cdots$ & - & $\cdots$ & $\cdots$ & $\cdots$ & $\cdots$ \\
\hline Supplier Facing IT & $\begin{array}{c}0.029 \\
(0.552)\end{array}$ & - & $\begin{array}{c}0.009 \\
(0.886)\end{array}$ & $\cdots$ & -- & $\cdots$ & $\cdots$ & $\cdots$ & $-\cdots$ \\
\hline Electronic & $\begin{array}{c}0.029 \\
(0.885)\end{array}$ & $\begin{array}{l}-0.235 \\
(0.206)\end{array}$ & $\begin{array}{c}-0.700 \\
(0.006)^{* *}\end{array}$ & $\begin{array}{c}-0.850 \\
(0.001)^{* * * *}\end{array}$ & $\begin{array}{c}0.109 \\
(0.477)\end{array}$ & $\begin{array}{l}-0.031 \\
(0.852)\end{array}$ & $\begin{array}{l}-0.164 \\
(0.392)\end{array}$ & $\begin{array}{c}0.109 \\
(0.609)\end{array}$ & $\cdots$ \\
\hline Machinery & $\begin{array}{c}-0.758 \\
(0.001)^{* * *}\end{array}$ & $\begin{array}{c}-0.881 \\
(0.000)^{* * * *}\end{array}$ & $\begin{array}{c}-1.778 \\
(0.000)^{* * *}\end{array}$ & $\begin{array}{c}0.012 \\
(0.968)\end{array}$ & $\begin{array}{c}0.560 \\
(0.001)^{* * *}\end{array}$ & $\begin{array}{c}0.354 \\
(0.060) \div\end{array}$ & $\begin{array}{c}0.233 \\
(0.285)\end{array}$ & $\begin{array}{c}0.288 \\
(0.254)\end{array}$ & -- \\
\hline Asian Plant & $\begin{array}{c}0.479 \\
(0.023)^{*}\end{array}$ & $\begin{array}{c}0.377 \\
(0.045)^{*}\end{array}$ & $\begin{array}{l}-0.265 \\
(0.303)\end{array}$ & $\begin{array}{c}0.643 \\
(0.020)^{*}\end{array}$ & $\begin{array}{c}-0.628 \\
(0.000)^{* * *}\end{array}$ & $\begin{array}{c}-0.361 \\
(0.035)^{*}\end{array}$ & $\begin{array}{c}-0.740 \\
(0.000)^{* * *}\end{array}$ & $\begin{array}{c}0.263 \\
(0.234)\end{array}$ & $\cdots$ \\
\hline USA Plant & $\begin{array}{c}0.139 \\
(0.648)\end{array}$ & $\begin{array}{l}-0.179 \\
(0.507)\end{array}$ & $\begin{array}{c}0.133 \\
(0.723)\end{array}$ & $\begin{array}{l}0.727 \dagger \\
(0.061)\end{array}$ & $\begin{array}{c}0.010 \\
(0.964)\end{array}$ & $\begin{array}{l}-0.236 \\
(0.334)\end{array}$ & $\begin{array}{l}-0.121 \\
(0.670)\end{array}$ & $\begin{array}{c}0.095 \\
(0.760)\end{array}$ & -- \\
\hline Chi-squared (p-value) & $\begin{array}{c}44.55 \\
(0.000)\end{array}$ & $\begin{array}{c}59.38 \\
(0.000)\end{array}$ & $\begin{array}{c}69.40 \\
(0.000)\end{array}$ & $\begin{array}{c}51.44 \\
(0.000)\end{array}$ & $\begin{array}{c}52.43 \\
(0.000)\end{array}$ & $\begin{array}{c}17.12 \\
(0.009)\end{array}$ & $\begin{array}{c}30.93 \\
(0.000)\end{array}$ & $\begin{array}{c}17.08 \\
(0.017)\end{array}$ & $\begin{array}{c}83.38 \\
(0.000)\end{array}$ \\
\hline R-squared & 0.2371 & 0.2947 & 0.3295 & 0.2347 & 0.2055 & 0.0923 & 0.1587 & 0.1134 & 0.3469 \\
\hline n & 140 & 140 & 140 & 140 & 140 & 140 & 140 & 140 & 140 \\
\hline
\end{tabular}

Notes: Values in parentheses are $p$-values; ${ }^{*} p<0.10,{ }^{*} p<0.05,{ }^{* * *} p<0.01,{ }^{* * *} p<0.001$.

association between project-level performance and overall market success (column 9).

\section{A. Antecedents of NPD Practices and Software Tool Use}

Table III (columns 1-3) presents results for the hypothesized drivers of the use of NPD practices and software tools (Hypotheses 1 and 2). In contrast to our expectation, we observe insignificant associations for the project scope variable. We observe that project complexity is positively associated with the use of design/validation tools $(\beta=0.346 ; p=0.000)$ and communication/teamwork tools $(\beta=0.432 ; p=0.000)$. Also, as hypothesized, project uncertainty is positively associated with the use of NPD practices $(\beta=0.566 ; p=0.004)$. In summary, we observe support for the proposed associations of Hypotheses 1B and 1C.

The customer facing IT and manufacturing plant IT infrastructure variables also indicate positive associations with the use of NPD practices and software tools. Customer facing IT is positively associated with NPD practices $(\beta=0.188 ; p=$ 0.001). Manufacturing plant IT is positively associated with the use of design/validation tools ( $\beta=0.027 ; p=0.013$ ). In con- trast, supplier facing IT exhibits no significant associations with practices or tools. In summary, we observe statistically significant associations providing some support for Hypotheses 2A and $2 \mathrm{~B}$.

We also observe statistically significant associations between the industry and region control variables and the extent of use of practices and tools. Specifically, the machinery industry segment exhibits negative coefficients, suggesting lower use of practices and tools on average. Asian plants appear to use NPD practices ( $\beta=0.479 ; p=0.023$ ) such as DFM, QFD, and RPT, and the design/validation tools $(\beta=0.377 ; p=0.045)$ to a greater extent.

\section{B. Consequences of NPD Practices and Tools Use}

Table III (columns 4-8) presents results for the hypothesized drivers of NPD project performance (Hypothesis 3). Timeto-market is positively associated with NPD practices $(\beta=$ $0.316 ; p=0.004)$, and weakly significantly associated with design/validation tools $(\beta=0.245 ; p=0.052)$, but insignificantly associated with communication/teamwork tools. Product performance quality exhibits strongly significant positive 
associations with the use of NPD practices $(\beta=0.198 ; p=$ $0.002)$ and design/validation tools $(\beta=0.277 ; p=0.000)$. Product conformance quality exhibits a significant positive association with NPD practices $(\beta=0.180 ; p=0.009)$, but no significant association with design/validation tools. Responsiveness also is strongly associated with NPD practices $(\beta=0.262$; $p=0.001)$, but weakly associated with the design/validation tools $(\beta=0.153 ; p=0.070)$. Finally, overall cost control is positively associated with NPD practices $(\beta=0.297 ; p=0.001)$, but not associated with the software tools. Overall, these findings provide very strong support for Hypothesis 3A and moderate support for several proposed relationships of Hypothesis 3B, but no support for Hypothesis 3C.

We also observe patterns among the control variables. First, the electronic segment exhibits a significantly worse time-tomarket $(\beta=-0.850 ; p=0.001)$. The machinery sector exhibits significantly higher performance quality $(\beta=0.560 ; p=0.001)$ and conformance quality $(\beta=0.354 ; p=0.060)$. Second, while U.S. plants show a weak significant time-to-market advantage $(\beta=0.727 ; p=0.061)$, Asian plants show significantly better time-to-market $(\beta=0.643 ; p=0.020)$ yet worse product performance quality $(\beta=-0.628 ; p=0.000)$, conformance quality $(\beta=-0.361 ; p=0.035)$, and responsiveness $(\beta=-0.740$; $p=0.000)$.

Finally, column 9 of Table III models the relationship between project-level performance metrics and overall market success (Hypothesis 4). Overall market success is positively associated with time-to-market ( $\beta=0.240 ; p=0.000)$, performance quality of the product designed $(\beta=0.237 ; p=0.032)$, and cost control of the project $(\beta=0.200 ; p=0.003)$. Overall market success is weakly associated with responsiveness $(\beta=0.163$; $p=0.057$ ). We did not observe a significant association between conformance quality and overall market success.

\section{DISCUSSION}

The purpose of this study is to advance NPD literature by examining the antecedents and consequences of the use of several NPD practices and software tools as well as to provide insights about choosing practices and tools that will be useful to NPD managers. The primary finding of this study is that compared with software tools, NPD practices are more strongly associated with better product outcomes, and, in turn, greater market success. The study also shows that the use of NPD practices and different types of software tools are driven by different project characteristics and types of available IT infrastructure. We discuss the theoretical and managerial implications of the results and explain how they relate to prior literature.

As the most important contribution of our study, our results (columns 4-8 in Table III) indicate that NPD practices are positively associated with all five project-level performance metrics, whereas design/validation tools are positively associated with only three project-level performance metrics, and communication/teamwork tools are insignificantly associated with the project-level performance metrics. Overall, NPD practices appear to be more important than software tools in driving NPD outcomes. To our knowledge, our study is among the few that juxtapose performance effects of NPD practices against those for various NPD software tools.

NPD practices create structural and procedural arrangements that NPD team members can follow to communicate and collaborate with each other. Since NPD practices enable multiple NPD team members to interact and communicate directly, these practices are particularly useful for NPD team members to solve the problems involving a great deal of ambiguity. In contrast, NPD software tools tend to be less effective for processing ambiguous information that needs a great deal of discussion, clarification, and debate. Given that NPD projects usually involve some uncertainty and ambiguity, it is not unexpected that NPD practices impact a broad set of project outcomes. Furthermore, even if a project manager decides that the NPD team she oversees should use certain software tools, the extent to which the software tools are used may still rest on individual team members. This is particularly true for generic software tools such as e-mail since collocated NPD team members in many circumstances may be more comfortable talking directly to each other rather than communicating via e-mails. The generic nature of communication/teamwork tools suggests that their usefulness to an NPD team may be overridden by NPD practices for team communication and coordination. The insignificant findings for communication/teamwork tools also may result from their high degree of use and generic nature. It is hard to imagine that a modern NPD team could function without using e-mail or PM software. Perhaps, in today's NPD environment, such generic software tools have become utilities to the NPD teams: everyone needs to use them, but they do not create significant competitive advantage.

Our results indicate that three of five project-level performance metrics (i.e., time-to-market, performance quality, and cost control) drive market success (column 9 in Table III). This finding is consistent with the performance metrics widely used in PM literature. However, our study provides independent empirical validation of the suitability of these three performance metrics across NPD projects within a global dataset representing multiple industries. Although a wide range of performance metrics is being used in the NPD literature, the metrics of time-to-market, cost control, and performance quality have the strongest associations with market success. This finding corroborates prior literature in that managers interested in market success should focus on building products faster, better, and cheaper [16].

Interestingly, design/validation software tools are positively associated with two of these three project-level performance metrics that drive product market success, suggesting the design tools' importance for NPD project success. This result seems to suggest that project managers may need to promote the use of design/validation tools since the tools are important to the project outcomes that lead to market success, and these software tools tend to be more technically sophisticated than the more generic communication/teamwork software tools, and therefore, may take more efforts for the NPD team members to use well. Finally, the insignificant design/validation tool findings suggest weaker impact on conformance quality and cost control than for NPD practices, even though design/validation tools 
possess functionality to analyze product conformance quality and to examine cost trade-offs. Future studies might examine whether such tools' effects upon conformance quality and cost are mediated by NPD practices.

Our results (columns 1-3 in Table III) provide two critical insights regarding the antecedents of NPD practices and software tool use: one insight relates to the effect of project characteristics, and the other insight relates to the effect of IT infrastructure. Among the three project characteristics examined in this study, the results indicate that only project uncertainty drives the use of NPD practices and only project complexity drives the use of design/validation and communication/teamwork software tools. As expected, project uncertainty drives the use of NPD practices that enable direct face-to-face communication, which are generally more effective for dealing with uncertain, ambiguous information. The finding that project complexity drives the use of both types of software tools is consistent with the theoretical prediction that NPD software tools are more effective for processing large amounts of complex information. Surprisingly, project scope has no significant relationship with NPD practices or software tools. Perhaps, project scope is not as direct as project complexity and uncertainty in capturing the different information processing needs of an NPD team. For instance, developing a completely new subsystem may involve more information processing challenges than developing a complete product that is largely based on a previous design. These findings provide useful insights about choosing the appropriate NPD practices or software tools under the contingencies of varying project characteristics. When a project involves a great deal of uncertainty, the project manager should promote the use of NPD practices that create the organizational infrastructure for team members to adequately communicate and coordinate for solving problems. If a project involves processing large amounts of structured, complex information, the project manager should encourage team members to use software tools, avoiding unnecessary group meetings and excessive personal means of communication and coordination that may consume lots of resources and time.

Among the three types of IT infrastructure, customer facing IT infrastructure drives the use of NPD practices, while manufacturing IT infrastructure drives the use of design/validation software tools. However, the study did not find any association between supplier facing IT infrastructure and the use of NPD practices or software tools. These findings are theoretically significant. Although scholars have suggested that availability of IT infrastructure is expected to facilitate greater use of software tools by NPD teams, prior studies did not find any significant association between generic, aggregated IT infrastructure variables and NPD software tool use [5], [21]. By breaking down IT infrastructure into three separate categories, our study is able to provide insights into the separate paths through which different IT infrastructure stimulates the use of NPD practices and tools. With customer facing IT infrastructure and NPD practices, customer IT infrastructure may enable more effective communication and information sharing with customers, and such information can be useful inputs for the NPD practices that integrate customers into the product development. Interest- ingly, manufacturing plant IT infrastructure only drives the use of design/validation tools. Modern manufacturing plant IT infrastructure allows the integration of design/validation software tools with broad plant IT systems, leading to convenient and effective use of these software tools. The availability of good manufacturing plant IT infrastructure is possibly less important to the use of communication/PM software tools because these tools can be conveniently used as stand-alone applications independently of plant wide IT systems. Surprisingly, supplier facing IT infrastructure shows no effect on the use of NPD practices or tools. Perhaps, supplier facing IT infrastructure is mainly used for transaction processing (e.g., order processing and inventory checking) rather than collaborative design. Availability of transaction-oriented supplier-facing IT infrastructure may be less significant to the NPD team's use of NPD practices or software tools.

The managerial implications of our findings are significant as these findings can be used as a compact set of guidelines for identifying appropriate NPD practices and software tools based on the characteristics of the NPD project. They imply that managers should promote the use of design/validation tools as these tools can facilitate faster time-to-market and improved product performance that drive overall market success. Project managers should advocate for the use of NPD practices for better team communication and coordination since using these NPD practices appears to be an effective way to improve a broad range of project-level performance metrics, and, in turn, overall market success. Project managers should carefully evaluate the impact of a project's complexity and uncertainty on the project's information processing needs, and accordingly, choose appropriate NPD practices and tools that are most effective in meeting these information processing needs. Finally, available IT infrastructure should be examined before making investment in NPD practices and software tools to achieve their full potential.

\section{CONCLUSION}

Many development practices and software tools are available to NPD teams to facilitate their NPD activities. Yet, while much has been written about these practices and tools, prior research has not untangled which of the tools are used, under what conditions they are used, or how their use may lead to better product design performance. This study addresses these issues and presents empirical estimates of the associations between antecedents and consequences of several commonly used NPD practices and software tools.

Prior studies either have examined the use of a single practice or software tool [13], [14] or examined highly aggregated IT applications [12], [16], [17]. In contrast, our study examines separate factors that drive the use of NPD practices and tools, as well as the impact of these practices and tools on NPD performance. These results present actionable insights for project managers about deploying appropriate practices and tools to drive project outcomes.

The study has several limitations that readers must consider to use the results presented here. One limitation is due to the cross-sectional nature of the data. Although cross-sectional data 
are widely used in the literature, it is never possible to conclusively establish causality with this type of data. Thus, valuable future research could examine the same issues using time-series panel data to explain variation in NPD practices and tools across multiple firms and time. Some construct measures used in this study are based on semantic scales that collect respondent opinions about aspects of NPD and plant functions. These questions were answered by a single respondent from the NPD team. It is possible that respondents' perceptions of the measurement items might be influenced by the plant where they work. Respondents also may have difficulty responding to Likert scales that lack universal objective anchors. We mitigated the influence of respondent bias by using different respondent sets for independent and dependent variables.

Researchers can pursue many future directions with respect to these NPD issues. Survey researchers could replicate our model by collecting multiple respondent data (i.e., for indi- vidual questions), and using multiple respondent surveys (i.e., between dependent and independent variables within a survey) to reduce possible CMB. Improved NPD surveys may help to more precisely estimate the impact of IT, NPD practices, and software tools upon NPD performance. Research could also estimate structural equation models through which a measurement model could be simultaneously estimated for each construct. Such models may better estimate mediation or moderation effects. Future study on qualitative outcomes of the use of NPD software tools may provide even more detailed information for managers about how using tools leads to improved project team dynamics that ultimately may drive better performance. Finally, researchers might observe NPD projects as they occur, to establish time separation between observation of NPD activities and the survey date for NPD project outcomes. Time separation may help to establish evidence regarding the causal impact of tools and practices.

APPENDIX A1

PRoject Characteristic AND NPD PERFormance VARIABLES

\begin{tabular}{|c|c|c|c|}
\hline Variables & Description of Items & $\begin{array}{l}\text { Factor } \\
\text { Loadings }\end{array}$ & $\begin{array}{l}\text { Composite } \\
\text { Reliability }\end{array}$ \\
\hline Project Scope & $\begin{array}{l}\text { Check the best description of the product: } 1 \text {. a part/component; } 2 \text {. a module; } \\
\text { 3. an assembly; } 4 \text {. a system }\end{array}$ & N/A & N/A \\
\hline $\begin{array}{l}\text { Project } \\
\text { Complexity }\end{array}$ & $\begin{array}{l}\text { This project included many tasks. } \\
\text { The tasks in this project were highly interdependent. } \\
\text { Overall, this was a relatively simple project. (R) }\end{array}$ & $\begin{array}{l}0.809 \\
0.467 \\
0.520\end{array}$ & 0.635 \\
\hline $\begin{array}{l}\text { Project } \\
\text { Uncertainty }\end{array}$ & $\begin{array}{l}\text { This product was: } \\
\text { 1. A derivative product based on modifications to existing products. } \\
\text { 2. A platform product for starting a new product line. } \\
\text { 3. A breakthrough product with new technology. } \\
\text { This product was: } \\
\text { 1. Similar to our existing products. } \\
\text { 2. Different from what we have manufactured, but similar to products } \\
\text { offered by our competitors. } \\
\text { 3. Different from what we have manufactured, and no similar products } \\
\text { were offered by our competitors. } \\
\text { The market for the product was: } \\
\text { 1. An existing market that we served. } \\
\text { 2. An existing market, but new to this company. } \\
\text { 3. The market did not exist prior to development of this product. } \\
\text { The product technology for this product was: } \\
\text { 1. Available within the company. } \\
\text { 2. New to the company, but available from outside. } \\
\text { 3. New to the world. } \\
\text { The process technology used to produce this product was: } \\
\text { 1. Similar to technology we had used before. } \\
\text { 2. Required major changes in existing manufacturing. } \\
\text { 3. Completely new. }\end{array}$ & $\begin{array}{l}0.372 \\
0.657\end{array}$ & 0.867 \\
\hline $\begin{array}{l}\text { Overall Market } \\
\text { Success }^{\mathrm{a}}\end{array}$ & $\begin{array}{l}\text { Overall profitability } \\
\text { Return on investment } \\
\text { Overall commercial success }\end{array}$ & $\begin{array}{l}0.902 \\
0.855 \\
0.678\end{array}$ & 0.856 \\
\hline Time to Market $^{\mathrm{a}}$ & Time to market & N/A & N/A \\
\hline $\begin{array}{l}\text { Product } \\
\text { Performance } \\
\text { Quality }^{\mathrm{b}}\end{array}$ & $\begin{array}{l}\text { Performance (functionality) } \\
\text { Features } \\
\text { Aesthetic appeal of the product } \\
\text { Customers' perception of the product }\end{array}$ & $\begin{array}{l}0.736 \\
0.770 \\
0.648 \\
0.704\end{array}$ & 0.807 \\
\hline $\begin{array}{l}\text { Product } \\
\text { Conformance } \\
\text { Quality }\end{array}$ & $\begin{array}{l}\text { Durability (life expectancy) } \\
\text { Reliability (time between failures) } \\
\text { Conformance quality }\end{array}$ & $\begin{array}{l}0.805 \\
0.878 \\
0.705\end{array}$ & 0.840 \\
\hline Responsiveness $^{\mathrm{b}}$ & $\begin{array}{l}\text { Our ability to customize the product } \\
\text { Our ability to rapidly deliver }\end{array}$ & $\begin{array}{l}0.627 \\
0.706\end{array}$ & 0.615 \\
\hline Cost Control $^{\mathrm{b}}$ & $\begin{array}{l}\text { Unit price } \\
\text { Unit cost of manufacturing }\end{array}$ & $\begin{array}{l}0.683 \\
0.850\end{array}$ & 0.743 \\
\hline
\end{tabular}

Notes: Superscript (a) indicates that respondents were asked to comment on NPD project goal outcomes: "Please rate the success of this product development project relative to its goals." Superscript (b) indicates respondents were asked to comment on product design outcomes: "Please compare this product to similar products manufactured and sold by your competitors." The symbol (R) indicates a reverse coded item. 


\section{APPENDIX A2}

\section{IT INFRASTRUCTURE VARIABLES}

\begin{tabular}{|c|c|}
\hline $\begin{array}{l}\text { Infrastructure } \\
\text { Variable }\end{array}$ & Description of Items \\
\hline $\begin{array}{l}\text { Customer Facing } \\
\text { IT }\end{array}$ & $\begin{array}{l}\text { For which of the following marketing and sales activities does your plant use the internet? } \\
\text { Presenting information about your plant } \\
\text { Presenting your sales product catalog } \\
\text { Providing on-line customized customer service, where customers can configure the product within the } \\
\text { constraints stated by the plant } \\
\text { Providing fixed pricing offers to potential buyers } \\
\text { Providing dynamic pricing offers to potential buyers } \\
\text { On-line order entry } \\
\text { Customers can check delivery status of their orders }\end{array}$ \\
\hline $\begin{array}{l}\text { Manufacturing } \\
\text { Plant IT }\end{array}$ & $\begin{array}{l}\text { Please check application areas supported by software applications at the plant: } \\
\text { Master production schedule } \\
\text { Rough cut capacity planning } \\
\text { Material requirements planning } \\
\text { Capacity requirements planning } \\
\text { Finite capacity scheduling } \\
\text { Shop floor control } \\
\text { Inventory management } \\
\text { Purchasing } \\
\text { Forecasting } \\
\text { Demand planning } \\
\text { Order management } \\
\text { Catalog and price management } \\
\text { Distribution management } \\
\text { Transportation management } \\
\text { Service management (after the sale) } \\
\text { Design (CAD, CAE)( } \dagger) \\
\text { Product data management }(\dagger) \\
\text { General accounting } \\
\text { Cost accounting } \\
\text { Budgeting } \\
\text { Human resource management } \\
\text { Maintenance management } \\
\text { Quality documentation management } \\
\text { Quality control and improvement } \\
\text { Performance measurement system } \\
\text { Project management }(\dagger) \\
\text { Workflow management } \\
\text { Business intelligence (query, reporting, OLAP, data mining) } \\
\text { Simulation and optimization of production and logistics planning }(\dagger) \\
\text { Groupware tools }(\dagger) \\
\text { Product configuration( } \dagger)\end{array}$ \\
\hline $\begin{array}{l}\text { Supplier Facing } \\
\text { IT }\end{array}$ & $\begin{array}{l}\text { For which of the following purchasing and supply activities does your plant use the Internet? } \\
\text { Scanning the marketplace for identification of potential sources } \\
\text { Receiving and comparing suppliers' offers } \\
\text { Providing dynamic pricing (negotiations and sellers' bids) for purchased items } \\
\text { Transmitting orders to suppliers } \\
\text { Tracking/tracing supply orders } \\
\text { Real-time integrated scheduling, shipping and warehouse management across the supplier network } \\
\text { Supporting collaborative product design/improvement with suppliers } \\
\text { Supporting collaborative process and technology design/improvement with suppliers }\end{array}$ \\
\hline \multicolumn{2}{|c|}{$\begin{array}{l}\text { Notes: The items were collected using a } \mathrm{Yes}(=1) / \mathrm{No}(=0) \text { checkbox approach. The variables used in the regression analysis for } \\
\text { customer Facing IT, manufacturing plant IT, and supplier facing IT were constructed by adding up the number of "yes" } \\
\text { responses for a firm. Heim and Peng [84] present factor analyses that examine the three sets of IT application variables, and } \\
\text { support constructing each variable in the form of an additive index that sums together the underlying items. }(\dagger)=\text { Upon reviewer } \\
\text { request, the items related to product development activities were omitted from the manufacturing plant IT variable to eliminate } \\
\text { any overlap with the NPD software tool variables. The results were very similar after omitting these items. }\end{array}$} \\
\hline
\end{tabular}

\section{ACKNOWLEDGMENT}

The authors gratefully acknowledge the insightful comments and constructive suggestions of the three anonymous reviewers and the editors on the earlier version of the paper. All errors and omissions are the responsibility of the authors.

\section{REFERENCES}

[1] S. Nambisan, "Information systems as a reference discipline for new product development," MIS Quart., vol. 27, no. 1, pp. 1-18, 2003.
[2] J. A. Fitzsimmons, P. Kouvelis, and D. N. Mallick, "Design strategy and its interface with manufacturing and marketing: A conceptual framework," J. Oper. Manage., vol. 10, no. 3, pp. 398-415, 1991.

[3] F. M. Hull, P. D. Collins, and J. K. Liker, "Composite forms of organization as a strategy for concurrent engineering effectiveness," IEEE Trans. Eng. Manag., vol. 43, no. 2, pp. 133-142, May 1996.

[4] J. E. Ettlie, "Integrated design and new product success," J. Oper. Manage., vol. 15, pp. 33-55, 1997.

[5] L. K. Moffat, "Tools and teams: Competing models of integrated product development project performance," J. Eng. Technol. Manage., vol. 15, no. 1 , pp. $55-85,1998$. 
[6] M. Swink, "A tutorial on implementing concurrent engineering in new product development programs," J. Oper.Manage., vol. 16, no. 1, pp. 103$116,1998$.

[7] D. N. Mallick, "The design strategy framework," Design Manage. J., vol. 11, no. 3, pp. 66-73, 2000.

[8] D. Gerwin and D. J. Barrowman, "An evaluation of research on integrated product development," Manage. Sci., vol. 48, no. 7, pp. 938-953, 2002.

[9] C. L. Tan and M. A. Vonderembse, "Mediating effects of computer-aided design usage: From concurrent engineering to product development performance," J. Oper. Manage., vol. 24, no. 5, pp. 494-510, 2006.

[10] G. Barczak, A. Griffin, and K. Kahn, "Trends and drivers of success in NPD practices: Results of the 2003 PDMA Best Practices Study,” J. Prod. Innov. Manage., vol. 26, no. 1, pp. 3-23, 2009.

[11] A. Rangaswamy and G. L. Lilien, "Software tools for new product development," J. Marketing Res., vol. 34, no. 1, pp. 177-184, 1997.

[12] G. Barczak, F. Sultan, and E. J. Hultink, "Determinants of IT usage and new product performance," J. Prod. Innov. Manage., vol. 24, no. 6 , pp. 600-613, 2007.

[13] G. Barczak, "New product strategy, structure, process and performance in the telecommunications industry," J. Prod. Innov. Manage., vol. 12, no. 3, pp. 224-234, 1995.

[14] R. D. Banker, I. R. Bardhan, and O. Asdemir, "Understanding the impact of collaboration software on product design and development," Inf. Syst. Res., vol. 17, no. 4, pp. 352-373, 2006.

[15] J. E. Ettlie and P. A. Pavlou, "Technology-based new product development partnerships," Decis. Sci., vol. 37, no. 2, pp. 117-147, 2006.

[16] I. R. Bardhan, V. V. Krishnan, and S. Lin, "Project performance and the enabling role of information technology: An exploratory study on the role of alignment," Manuf. Serv. Oper. Manage., vol. 9, no. 4, pp. 579-595, 2007.

[17] S. S. Durmuşoğlu, G. Barczak, and F. Sultan, "Do information technology tools foster new product performance? A new product development phasebased analysis of effects," presented at the PDMA Res. Conf., Orlando, FL, 2008

[18] M. Bowden, "Report on the role of IT in new product development today," in Proc. Prod. Dev. Manage. Assoc. Conf. (PDMA), Jan. 2004, pp. I-1-8.

[19] M. Ozer, "Process implications of the use of internet in new product development: A conceptual analysis," Ind. Marketing Manage., vol. 32, pp. 517-530, 2003.

[20] R. D. Banker, I. R. Bardhan, H. Chang, and S. Lin, "Plant information systems, manufacturing capabilities, and plant performance," MIS Quart., vol. 30 , no. 2, pp. 315-337, 2006.

[21] M. McGrath and M. Iansiti, "Envisioning IT-enabled product development," PRTM Insight Mag., pp. 1-12, Fall/Winter 1998

[22] S. Thomke, "Simulation, learning, and R\&D performance: Evidence from automotive development," Res. Policy, vol. 27, pp. 55-74, 1998.

[23] L. P. Cooper, "A research agenda to reduce risk in new product development through knowledge management: A practitioner perspective," $J$. Eng. Technol. Manage., vol. 20, pp. 117-140, 2003.

[24] T. Dewitt and G. Jones, "The role of information technology in the organization: A review, model and assessment," J. Manage., vol. 27, no. 3, pp. 313-246, 2001

[25] D. Farrell, "The real new economy," Harvard Bus. Rev., vol. 81, no. 10 pp. 104-112, 2003.

[26] A. Menon, J. Chowdhury, and B. A. Lukas, "Antecedents and outcomes of new product development speed: An interdisciplinary conceptual framework," Ind. Marketing Manage., vol. 31, no. 4, pp. 317-328, 2002.

[27] M. Ozer, "Information technology and new product development," Ind. Marketing Manage., vol. 29, pp. 387-339, 2000

[28] R. Boutellier, O. Gassman, H. Macho, and M. Roux, "Management of dispersed product development teams: The role of information technologies," $R \& D$ Manage., vol. 28, no. 1, pp. 13-25, 1998.

[29] A. Hameri and J. Nihtilä, "Distributed new product development project based on internet and world-wide web: A case study," J. Prod. Innov. Manage., vol. 14, no. 2, pp. 77-87, 1997.

[30] A. Malhotra, A. Majchrzak, R. Carman, and V. Lott, "Radical innovation without collocation: A case study at Boeing-Rocketdyne," MIS Quart., vol. 25, no. 2, pp. 229-249, 2001.

[31] I. R. Bardhan, "Toward a theory to study the use of collaborative product commerce for product development," Inf. Technol. Manage., vol. 8, pp. 167-184, 2007

[32] E. F. McDonough, K. Khan, and A. Griffin, "Managing communication in global product development teams," IEEE Trans. Eng. Manag., vol. 46, no. 4, pp. 375-386, Nov. 1999.
[33] A. M. Sánchez and M. P. Peréz, "Cooperation and the ability to minimize the time and cost of new product development within the Spanish automotive supplier industry," J. Prod. Innov. Manage., vol. 20, no. 1, pp. 57-69, 2003

[34] E. Kessler and A. Chakrabarti, "Speeding up the pace of new product development," J. Prod. Innov. Manage., vol. 16, pp. 231-247, 1999.

[35] M. Fleischer and J. K. Liker, Concurrent Engineering Effectiveness: Integrating Product Development Across Organizations. $\quad$ Cincinnati, $\mathrm{OH}$ : Hanser-Gardner Publications, 1997.

[36] A. V. Citrin, R. P. Lee, and J. McCullough, "Information use and new product outcomes: The contingent role of strategy type," J Prod. Innov. Manage., vol. 24, pp. 259-273, 2007.

[37] S. Thomke, "Capturing the real value of innovation tools," Sloan Manage. Rev., vol. 47, no. 2, pp. 24-32, 2006.

[38] C. Terwiesch, C. Loch, C., and A. De Meyer, "Exchanging preliminary information in concurrent engineering," Org. Sci., vol. 13, no. 4, pp. 402419, 2002.

[39] E. M. Olson, O. C. Walker, and R. W. Ruekert, "Organizing for effective new product development: The moderating role of product innovativeness," J. Marketing, vol. 59, no. 1, pp. 48-62, 1995.

[40] B. J. Zirger and J. L. Hartley, "The effect of acceleration techniques on product development time," IEEE Trans. Eng. Manag., vol. 43, no. 2, pp. 143-152, May 1996.

[41] V. Krishnan and K. T. Ulrich, "Product development decisions: A review of the literature," Manage. Sci., vol. 47, no. 1, pp. 1-21, 2001.

[42] M. V. Tatikonda and S. R. Rosenthal, "Technology novelty, project complexity, and product development project execution success: A deeper look at task uncertainty in product innovation," IEEE Trans. Eng. Manag., vol. 47, no. 1, pp. 74-87, Feb. 2000.

[43] E. Veldhuizen, E. J. Hultink, and A. Griffin, "Modeling market information processing in new product development: An empirical analysis," J. Eng. Technol. Manage., vol. 23, pp. 353-373, 2006.

[44] E. J. Hultink, K. Talke, A. Griffin, and E. Veldhuizen, "Market information processing in new product development: The importance of process interdependency and data quality," IEEE Trans. Eng. Manag., vol. 58, no. 2, pp. 199-211, May 2011.

[45] J. R. Galbraith, "Organization design: An information processing view," Interfaces, vol. 4, no. 3, pp. 28-36, 1974.

[46] P. J. Kitchen and G. Spickett-Jones, "Information processing: A critical literature review and future research directions," Int. J. Market Res., vol. 45, no. 1, pp. 73-98, 2003.

[47] M. Swink, "Product development-faster, on-time," Res. Tech. Manage., vol. 45, no. 4, pp. 50-58, 2002.

[48] M. Swink and A. Nair, "Capturing the competitive advantages of AMT: Design-manufacturing integration as a complementary asset," J. Oper. Manage., vol. 25, pp. 736-754, 2007.

[49] R. Schmidt, "The implementation of simultaneous engineering in the stage of product concept development: A process orientated improvement of quality function deployment," Eur. J. Oper. Res., vol. 100, no. 2, pp. 293-314, 1997.

[50] J. R. Hauser and D. Clausing, "The house of quality," Harvard Bus. Rev., vol. 66, no. 3, pp. 63-73, 1988.

[51] Q. Zhang, M. A. Vonderembse, and M. Cao, "Product concept and prototype flexibility in manufacturing: Implications for customer satisfaction," Eur. J. Oper. Res., vol. 194, no. 1, pp. 143-154, 2009.

[52] T. H. Davenport, Process Innovation: Reengineering Work through Information Technology. Cambridge, MA: HBS Press, 1993.

[53] G. P. Huber, "A theory of the effects of advanced information technologies on organizational design, intelligence, and decision making," Acad. Manage. Rev., vol. 15, no. 1, pp. 47-71, 1990.

[54] L. Z. Song and M. Song, "The role of information technologies in enhancing R\&D-marketing integration: An empirical investigation," J. Prod. Innov. Manage., vol. 27, pp. 382-401, 2010.

[55] A. Yassine, K. C. Kim, T. Roemer, and M. Holweg, "Investigating the role of IT in customized product design," Prod. Plann. Control, vol. 15, no. 4, pp. 422-434, 2004.

[56] K. B. Clark, "Project scope and project performance: The effect of parts strategy and supplier involvement on product development," Manage. Sci., vol. 35, no. 10, pp. 1247-1263, 1989.

[57] M. Ozer, "Factors which influence decision making in new product evaluation," Eur. J. Oper. Res., vol. 163, no. 3, pp. 784-801, 2005.

[58] O. Hauptman and K. K. Hirji, "The influence of process concurrency on project outcomes in product development: An empirical study of crossfunctional teams," IEEE Trans. Eng. Manag., vol. 43, no. 2, pp. 153-164, May 1996. 
[59] K. E. Weick, Social Psychology of Organizing. Reading, MA: AddisonWesley, 1979.

[60] R. L. Daft and R. H. Lengel, "Organizational information requirements, media richness and structural design," Manage. Sci., vol. 32, no. 5, pp. 554-571, 1986.

[61] X. A. Koufteros, M. A. Vonderembse, and W. J. Doll, "Integrated product development practices and competitive capabilities: The effects of uncertainty, equivocality, and platform strategy," J. Oper. Manage., vol. 20, no. 4, pp. 331-355, 2002.

[62] S. L. Brown and K. M. Eisenhardt, "Product development: Past research, present findings, and future directions," Acad. Manage. Rev., vol. 20, no. 2, pp. 343-378, 1995.

[63] P. Weill, M. Subramani, and M. Broadbent, "Building IT infrastructure for strategic agility," Sloan Manage. Rev., vol. 44, no. 1, pp. 57-65, 2002.

[64] N. Melville, K. Kraemer, and V. Gurbaxani, "Information technology and organizational performance: An integrative model of IT business value," MIS Quart., vol. 28, no. 2, pp. 283-322, 2004.

[65] N. B. Duncan, "Capturing flexibility of information technology infrastructure: A study of resource characteristics and their measure," J. Manage. Inf. Syst., vol. 12, no. 2, pp. 37-56, 1995.

[66] J. Lin, Y. Qian, W. Cui, and Z. Miao, "Overlapping and communication policies in product development," Eur. J. Oper. Res., vol. 201, no. 3 , pp. 737-750, 2010.

[67] D. N. Mallick and R. G. Schroeder, "An integrated framework for measuring product development performance in high technology industries," Prod. Oper. Manage., vol. 14, no. 2, pp. 142-158, 2005.

[68] E. H. Kessler and P. E. Bierly, "Is faster really better? An empirical test of the implications of innovation speed," IEEE Trans. Eng. Manag., vol. 49, no. 1, pp. 2-12, Feb. 2002.

[69] J. Chen, R. R. Reilly, and G. S. Lynn, "The impacts of speed-to-market on new product success: The moderating effects of uncertainty," IEEE Trans. Eng. Manag., vol. 52, no. 2, pp. 199-212, May 2005.

[70] W. H. A. Johnson, Z. Piccolotto, and R. Filippini, "The impacts of time performance and market knowledge competence on new product success: An international study," IEEE Trans. Eng. Manag., vol. 56, no. 2, pp. 219 228, May 2009.

[71] K. B. Clark and T. Fujimoto, Product Development Performance: Strategy, Organization, and Management in the World Auto Industry. Boston, MA: HBS Press, 1991.

[72] C. Chen, "Information technology, organizational structure, and new product development-The mediating effect of cross-functional team interaction," IEEE Trans. Eng. Manag., vol. 54, no. 4, pp. 687-697, Nov. 2007.

[73] S. Kotha, "Mass customization: Implementing the emerging paradigm for competitive advantage," Strateg. Manage. J., vol. 16, pp. 21-42, 1995.

[74] P. A. Pavlou and O. A. El Sawy, "From IT leveraging competence to competitive advantage in turbulent environments: The case of new product development," Inf. Syst. Res., vol. 17, no. 3, pp. 198-227, 2006.

[75] P. A. Pavlou and O. A. El Sawy, "The 'Third Hand': IT-enabled competitive advantage in turbulence through improvisational capabilities," Inf. Syst. Res., vol. 21, no. 3, pp. 443-471, 2010.

[76] M. V. Tatikonda and M. M. Montoya-Weiss, "Integrating operations and marketing perspectives of product innovation: The influence of organizational process factors and capabilities on development performance," Manage. Sci., vol. 47, no. 1, pp. 151-172, 2001.

[77] R. G. Schroeder and B. B. Flynn, High Performance Manufacturing: Global Perspectives. $\quad$ New York: Wiley, 2001.

[78] P. M. Podsakoff and D. W. Organ, "Self-reports in organizational research: Problems and prospects," J. Manage., vol. 12, no. 4, pp. 531-544, 1986.

[79] P. M. Podsakoff, S. B. MacKenzie, J. Lee, and N. P. Podsakoff, "Common method biases in behavioral research: A critical review of the literature and recommended remedies," J. Appl. Psychol., vol. 88, no. 5, pp. 879-903, 2003

[80] K. Bollen, Structural Equations With Latent Variables. New York: Wiley, 1989.

[81] A. Zellner, "An efficient method of estimating seemingly unrelated regressions and tests for aggregation bias," J. Amer. Stat. Assoc., vol. 57 , pp. 348-368, 1962.

[82] W. H. Greene, Econometric Analysis, 6th ed. Upper Saddle River, NJ: Pearson-Prentice-Hall, 2008.
[83] StataCorp, Stata Statistical Software: Release 10. College Station, TX: StataCorp LP, 2007.

[84] G. R. Heim and D. X. Peng, "The impact of information technology use on plant structure, practices, and performance: An exploratory study," $J$. Oper. Manage., vol. 28, no. 2, pp. 144-162, 2010.

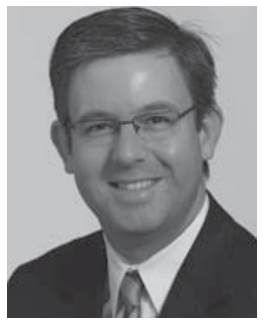

Gregory R. Heim received the A.B. degree in economics from The University of Chicago, Chicago, IL, and the Ph.D. degree in operations and management science from the Carlson School of Management, University of Minnesota, Minneapolis.

$\mathrm{He}$ is currently an Associate Professor in the Department of Information and Operations Management, Mays Business School, Texas A\&M University, College Station. He has authored or coauthored papers in several journals including Decision Sciences, Journal of Operations Management, Journal of Service Research, Manufacturing and Service Operations Management, and Production and Operations Management. His current research interests include service and e-service operations, management of technology, quality management, mass customization, and retail supply chain management. A major focus of his empirical research program concerns how information technology supports operations.

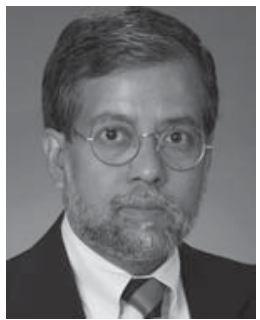

Debasish N. Mallick (M'92) received the B.Tech. (Honors) degree in mechanical engineering from the Indian Institute of Technology, kharagpur, India, in 1980, the M.B.A. degree from the University of Arkansas, Fayetteville, in 1987, and the Ph.D. degree in management from the University of Texas, Austin, in 1993.

He is currently an Associate Professor of operations and supply chain management in Opus College of Business, University of St. Thomas, Minneapolis, MN. Previously, he has worked in manufacturing and service sectors in the USA and abroad, and taught at Virginia Commonwealth University, Boston College, and University of Minnesota. He has authored and coauthored papers in the Journal of Operations Management, Production and Operations Management, Journal of Engineering and Technology Management, Design Management Journal, European Journal of Operational Research, European Journal of Innovation Management, and Journal of Product Innovation Management. His current research interests include new product development and technology management.

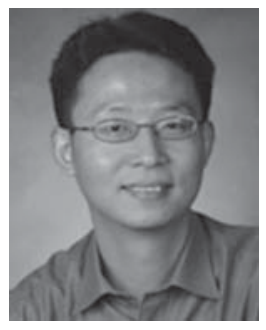

Xiaosong (David) Peng received the M.A. degree in information systems from Carnegie Mellon University, Pittsburgh, PA, and the Ph.D. degree in operations and management science from the Carlson School of Management, University of Minnesota, Minneapolis.

He is currently an Assistant Professor in the Department of Information and Operations Management, Mays Business School, Texas A\&M University, College Station. He has authored and coauthored papers in the Journal of Operations Management, Decision Sciences, International Journal of Production and Operations Management, and International Journal of Production Research. His current research interests include information technology impact on manufacturing and service processes, and supply chain strategy. 